\title{
PENGARUH LAMA PENYIMPANAN DAHAK PAGI PADA SUHU KAMAR TERHADAP JUMLAH BAKTERI TAHAN ASAM (BTA)
}

\author{
The Effect Of The Duration Of Morning Phelgm Storage At Room Temperature On The
} Number Of Acid Resistant Bacteria

Wa Ode NurAlfiyani Muin ${ }^{1}$, Kalma $^{2}$, Artati $^{3}$, Rafika $^{4}$

${ }^{1}$ Prodi Sarjana Terapan Teknologi Laboratorium Medis Poltekkes Kemenkes Makassar

${ }^{2,3,4}$ Jurusan Analis Kesehatan Poltekkes Kemenkes Makassar

Korespondensi: rafikauddinramli@gmail.com/082345553522

\begin{abstract}
Tuberculosis is a bacterial infection of mycobacterium tuberculosis that attacks and damages the tissues of the human body. Bacteria can be transmitted through tuberculosis airways that usually attack the lung but usually also puncture bones, lymph nodes, central nervous system, heart, and other organs. Phlegm testing directly revives many weaknesses, namely a lot of mucus and tissues that will increase the volume of samples so that it will reduce the chances of developing mycobacterium tuberculosis. Therefore, to increase the effectiveness of microscopic examination of phlegm, 4\% $\mathrm{NaOH}$ sample samples can be processed so that BTA will be collected in smaller volumes and more likely to obtain samples containing germs. This study was conducted with 3 treatments, namely morning phlegm that was examined immediately, morning phlegm delayed by 3 hours, and morning phlegm delayed 6 hours later decontaminated and examined with a microscope to see how big the effect. Variance test results (ANOVA), found that the significant value of the ANOVA test 1,000>0.05 had no significant influence between the phlegm examined and directly delayed 3 hours and delayed 6 hours. The conclusion that the length of storage of sputum in the morning at room temperature was checked immediately, delayed 3 hours and delayed 6 hours did not affect the number of acidresistant bacteria (BTA) $(\rho=1,000)$. But there was no significant influence on the length of time sputum was stored in the morning, the researchers still segmented that they still use morning phlegm that is immediately examined to still get good quality phlegm and test results.
\end{abstract}

Keywords: Storage Length, Sample Decontamination, Inspection (BTA)

\begin{abstract}
ABSTRAK
Tuberkulosis adalah infeksi bakteri mycobacterium tuberculosis yang menyerang dan merusak jaringan tubuh manusia. Bakteri dapat ditularkan melalui saluran udara tuberkulosis yang biasanya menyerang lugn tetapi biasanya juga menusuk tulang, kelenjar getah bening, sistem saraf pusat, jantung, dan organ lainnya. Pemeriksaan dahak secara langsung menghidupkan kembali banyak kelemahan yaitu banyak lendir dan jaringan yang akan meningkatkan volume sampel sehingga akan mengurangi kemungkinan terkena mikrobakterium tuberculosis. Oleh karena itu, untuk meningkatkan efektivitas pemeriksaan mikroskopis dahak, sampel sampel $\mathrm{NaOH} \mathrm{4 \%} \mathrm{dapat} \mathrm{diproses} \mathrm{sehingga} \mathrm{BTA}$ akan dikumpulkan dalam volume yang lebih kecil dan lebih mungkin untuk mendapatkan sampel yang mengandung kuman. Penelitian ini dilakukan dengan 3 perlakuan, yaitu
\end{abstract}


dahak pagi yang diperiksa segera, dahak pagi tertunda 3 jam, dan dahak pagi tertunda 6 jam kemudian didekontaminasi dan diperiksa dengan mikroskop untuk melihat seberapa besar pengaruhnya. Hasil uji Varians (ANOVA), ditemukan bahwa nilai signifikan dari uji ANOVA 1.000>0,05 tidak memiliki pengaruh yang signifikan antara dahak yang diperiksa dan langsung tertunda 3 jam dan tertunda 6 jam. Simpulan bahwa lama penyimpanan dahak pagi hari pada suhu kamar diperiksa segera, ditunda 3 jam dan ditunda 6 jam tidak berpengaruh pada jumlah bakteri tahan asam (BTA) $(\rho=1.000)$. Namun tidak ada pengaruh yang signifikan terhadap lamanya menyimpan dahak di pagi hari, para peneliti masih melakukan segmentasi bahwa mereka masih menggunakan dahak pagi yang segera diperiksa agar tetap mendapatkan kualitas dahak dan hasil pemeriksaan yang baik.

Kata kunci : Lama Penyimpanan, Dekontaminasi Sampel, Pemeriksaan (BTA)

\section{PENDAHULUAN}

Tuberculosis merupakan infeksi bakteri mycobacterium tuberculosis yang menyerang dan merusak jaringan tubuh manusia. Bakteri tersebut dapat ditularkan melalui saluran udara. TBC biasanya menyerang paru paru, namun biasa juga menyebar ke tulang, kelenjar getah bening, system saraf pusat, jantung dan organ lainnya. (Samiadi, 2017).

Tuberculosis (TBC) menjadi salah satu dari 10 penyakit mematikan di Dunia (Aprianda, 2018). Diperkirakan terdapat 8,6 juta kasus TB pada tahun 2012 dimana 1,1 juta orang (13\%) diantaranya adalah pasien dengan HIV positif. Sekitar 75\% dari pasien tersebut berada di wilayah Afrika, pada tahun 2012 diperkirakan terdapat 450.000 orang yang menderita TB MDR dan 170.000 diantaranya meninggal dunia. Pada tahun 2012 diperkirakan proporsi kasus TB anak diantara seluruh kasus TB secara global mencapai $6 \%$ atau 530.000 pasien TB anak pertahun, atau sekitar $8 \%$ dari total kematian yang disebabkan oleh TB. (WHO, 2013)

Pada tahun 2016, terdapat 274 kasus kematian perhari di Indonesia, pada tahun yang sama juga, kasus TBC baru mencapai 1.020 .000 pengidap. Angka itu menjadikan Indonesia berada di peringkat ke 2 kasus TBC terbanyak di
Dunia setelah India. Kemudian disusul oleh China, Filipina, Pakistan, Nigeria dan Afrika selatan. Diperkirakan ada 1.020.000 kasus TB di Indonesia, namun baru terlapor ke Kementerian Kesehatan sebanyak 420.000 kasus. Jumlah tersebut mengalahkan Tiongkok di urutan ketiga yang memiliki sekitar 1,4 milyar penduduk. Hanya satu negara yang lebih buruk jumlah kasus TB-nya dari Indonesia, yakni India yang memiliki jumlah penduduk 1,3 milyar. (WHO,2017)

Banyaknya kasus TB tersebut, maka dilakukan pemeriksaan bakteriologis yang salah satunya adalah pemeriksaan dahak mikroskopis. Pemeriksaan dahak langsung tanpa pengolahan telah banyak dilakukan di tempat awal pemeriksaan penderita, namun cara ini masih banyak kelemahan yaitu, banyak lendir dan jaringan yang memperbesar volume sampel, sehingga akan memperkecil kemungkinan untuk dapat mengambil sampel yang mengandung mycobacterium tuberculosis. Oleh karena itu untuk meningkatkan efektifitas pemeriksaan mikroskopik dahak dapat dilakukan pengolahan sampel metode homogenisasi dengan $\mathrm{NaOH} 4 \%$ sehingga BTA akan dikumpulkan dalam volume yang lebih kecil serta akan memperbesar kemungkinan untuk mengambil sampel 
yang mengandung kuman. (Darmawati, 2013)

Pemeriksaan dahak untuk menegakkan diagnosa dilakukan dengan mengumpulkan 3 spesimen dahak yang dikumpulkan dalam dua hari kunjungan yang berurutan berupa sewaktu (S) pertama kali penderita datang, pagi (P) keesokan harinya apabila penderita datang lagi membawa dahak pagi (dahak pertama setelah bangun tidur), sewaktu (S) saat penderita tiba di laboratorium penderita diminta untuk mengeluarkan dahaknya lagi (SPS). Sebelum melakukan pempuatan sediaan sputum, petugas laboratorium harus memeriksa secara fisik yaitu dipilih yang kental, purelen berwarna hijau kekuningan, kadang ada bercak darah agar dalam pembuatan sediaan jadi lebih berkualitas. (Budiharjo, 2016)

Untuk pemeriksaan BTA harus menggunakan sampel sputum yang baik sesuai dengan standar sehingga menghasilkan hasil diagnosis yang baik agar tidak terjadi positif palsu maupun negatif palsu dan hal hal yang tidak diinginkan lainnya. Biasanya sampel yang baik untuk di jadikan pemeriksaan adalah sampel sputum pagi yang dikeluarkan pasien saat pagi hari saat bangun tidur karena dahak pada pagi hari adalah dahak yang masih memiliki banyak kuman. Sampel tersebut dihasilkan sebelum makan atau minum dan sebelum menggosok gigi, tetapi sudah berkumur dengan air untuk bisa membersihkan sisa makanan dalam mulut yang tertinggal. Sputum yang memenuhi syarat harus betul betul dari trakea dan bronki bukan berupa air ludah. (Fujiki, 2015)

Kualitas sampel sangat mempengaruhi jumlah basil tahan asam. Dalam hal ini, jumlah BTA pada sampel yang dilakukan penundaan pemeriksaan, karena biasanya pada lapangan kerja terjadi penundaan sampel disebabkan banyaknya sampel yang ditangani oleh petugas laboratorium, sehingga sering kali dilakukan penundaan pemeriksaan. Tujuannya untuk mengetahui pengaruh lama penyimpanan dahak pagi pada suhu kamar terhadap jumlah bakteri tahan asam.

\section{METODE}

Jenis penelitian merupakan eksperimen semu dengan rancangan dalam menentukan seberapa besar pengaruh lama penyimpanan dahak pagi pada suhu kamar terhadap jumlah bakteri tahan asam (BTA).

Peneltian dilakukan di Laboratorium Mikrobiologi Balai besar kesehatan paru masyarakat Makassar, pada bulan Maret sampai dengan April 2019. Populasi, seluruh penderita TB di Balai Besar Kesehatan Paru Masyarakat Makassar. Sampel adalah penderita TB paru positif, dan penderita $\mathrm{Tb}$ paru dengan besar sampel sebanyak 9 sampel. Teknik Pengambilan Sampel adalah accidental sampling.

\section{Prosedur penelitian}

1. Persiapan pasien

Pasien diberi penjelasan tentang batuk yang benar untuk mendapatkan dahak (sputum) yang kental dan purelen. Sampel berupa dahak (sputum) ditampung dalam pot yang bermulut lebar, berpenampung $6 \mathrm{~cm}$ atau lebih dengan tutup berulir, tidak mudah pecah dan tidak bocor.

Alat terdiri dari mikroskop, rak pewarnaan, slide/objek glass, lampu spiritus, tusuk sate, mixer turbo, centrifuge, pipet, tabung centrifuge.

Bahan diantaranya dahak, Reagen yaitu carbol fuchsin 0,3\%, HCl-alkohol $3 \%$, methylene blue $0,3 \%$, auadest, dan oil emersi, $\mathrm{NaOH} 4 \%$, phosphate buffer saline (PBS).

2. Cara pembuatan preparat: 
Melakukan pengenceran sampel sputum menggunakan $\mathrm{NaOH} 4 \%$ dengan perbandingan 1:1 $(1 \mathrm{ml}$ sampel:1ml $\mathrm{NaOH}$ ). Dihomogenkan menggunakan alat mixer turbo, divortex selama beberapa detik, dipastikan spesimen benar-benar tercampur. Dibiarkan selama 15 menit pada suhu kamar. Kemudian ditambahkan phosphate buffer saline (PBS) ph 6,8 sampai 7,0 hingga volume $45 \mathrm{ml}$, setelah itu Disentrifuge specimen dengan kecepatan $3000 \mathrm{G}$ selama 15 menit. Supernatant dibuang secara perlahan dan endapan ditambahkan $1 \mathrm{ml}$ PBS 6,8-7,0. Selanjutnya hasil dekontaminasi dibuat preparat dengan bantuan pipet sebanyak $100 \mu \mathrm{l}$,

Pembuatan sediaan dari bahan pemeriksaan, ratakan diatas gelas objek dengan ukuran kurang lebih $2 \times 3 \mathrm{~cm}$, panjang sediaan $3 \mathrm{~cm}$ dan lebar $2 \mathrm{~cm}$, sediaan jangan terlalu tebal atau tipis, sediaan kemudian dihotplate lalu dilakukan pewarnaan BTA.

Pewarnaan ditempatkan lalu diteteskan sediaan dengan carbol fuchsin sampai menutupi seluruh permukaan objek glass, dengan api kecil, panasi sediaan dari bawah (tidak boleh mendidih) hal ini, dilakukan 3 kali dalam waktu 5 menit, dibilas sediaan dengan air mengalir, lalu larutkan dengan Hcl-Alkohol 3\% sampai semua zat warna keluar, bilas dengan air, lalu tetesi dengan larutan methylene blue selama 30 detik. Bilas dengan air mengalir, sediaan dikeringkan diatas rak pengering diudara terbuka (jangan sampai terkena matahari langsung). Kemudian pengamatan mikroskopik.

Menghitung jumlah bakteri basil tahan asam (BTA) per $100 \mu 1$ endapan dahak yang diencerkan dengan phosphate buffer saline.(PBS).

\section{Analisis data}

Untuk melihat adanya pengaruh penyimpanan dahak pagi dalam pemeriksaan BTA ini digunakan uji analysis of varience (ANOVA)

\section{HASIL}

Terdapat 9 sampel sputum pada penderita tuberculosis paru, dimana dalam 1 sampel dilakukan 3 perlakuan pemeriksaan yang sebelumnya telah dilakukan proses dekontaminasi sputum. Dari hasil penelitian diperoleh karakteristik responden diantaranya berdasarkan umur terdapat 5 orang $(55,6 \%)$ umur 20-34 tahun. Jenis kelamin laki-laki terbanyak 6 orang (66,7\%), lihat Tabel 01 dan 02.

Jumlah BTA dari hasil pemeriksaan dahak dengan waktu segera, tunda 3 jam dan tunda 6 jam. Dilakukan uji normalitas data yaitu uji Shapiro-wilk yang diperoleh data normal ketiga hasil jumlah BTA yaitu nilai sig. 0,06; 0,06, $0,06>$ sig. 0,05, Tabel 03, maka syarat ini terpenuhi untuk analisis ANOVA. Syarat selanjutnya untuk melakukan analisis ANOVA dengan uji homegenitas agar varians data sama dari masing-masing kelompok. Varian data diuji dengan Levene Test. Hasil ini diperoleh sig. 1,000, hal berarti lebih besar dari nilai sig.0,05, seperti Tabel 04. Maka syarat kedua telah terpenuhi dan dilanjutkan uji ANOVA.

Hasil analisis uji ANOVA dari jumlah BTA pada perlakuan pemeriksaan dahak waktu segera, tunda 3 jam dan tunda 6 jam diperoleh nilai sig. 1,000, dapat dilihat Tabel 05 . Berarti tidak ada perbedaan antara masing-masing waktu pemeriksaan dahak. Dapat disimpulkan tidak ada pengaruh lamanya penyimpanan dahak pagi terhadap jumlah kuman BTA.

\section{PEMBAHASAN}

Penelitian ini yang memiliki 9 sampel, yang mana karakteristik umur yang terbanyak 20-34 tahun dan jenis kelami laki-laki. Hal ini karena kaitan 
umur tersebut dan laki-laki yang lebih banyak interaksi di luar, sehingga peluang lebih mudah terkontaminasi atau tertular kuman TB.

Pada tabel 03 didapat jumlah maksimum bakteri pada dahak yang diperiksa segera sebanyak 2322 BTA dan jumlah minimum bakteri pada dahak yang diperiksa segera berjumlah 55 BTA, sedangkan jumlah maksimum bakteri pada dahak yang ditunda 3 jam sebanyak 2315 BTA, dan jumlah minimum bakteri pada dahak yang diperiksa tunda 3 jam sebanyak 52 BTA, dan jumlah bakteri maksimum pada dahak yang diperiksa tunda 6 jam sebanyak 2310 BTA dan jumlah minimum bakteri pada dahak yang diperiksa tunda 6 jam sebanyak 50 BTA.

$\begin{array}{ccc}\text { Setelah } & \text { didapatkan hasil } \\ \text { pemeriksaan } & \text { tersebut } & \text { maka }\end{array}$
dilakukanlah uji statistikANOVA, akan tetapi sebelum melakukan uji ANOVA hal pertama yang akan dilakukan yaitu uji normalitas datauntuk melihat apakah data tesebut normal ataukah tidak, untuk memenuhi salah satu syarat uji ANOVA.

Uji normalitas dapat menggunakan uji kolmogorov smirnov jika responden > 50 sampel, karena pada peneltian ini responden hanya 9 maka, uji normalitas data menggunakan uji Shapiro-wilk.

Seperti berdasarkan tabel 4.4 uji Shapiro wilk dapat dilihat bahwa nilai signifikansi (Sig.) data pemeriksaan Segera sebesar 0,061, Tunda 3 Jam sebesar 0,060 dan Tunda 6 Jam sebesar 0,060. Ketiga varians data diatas menunjukan nilai Sig. > 0,05. Dengan demikian sebaran data responden pada penelitian ini terdistribusi normal.Setelah dilakukan uji normalitas data,maka dilakukanlah uji homogenitas data

Berdasarkan tabel 4.5 uji homogenitas datadidapatkan hasil analisis bahwa nilai signifikansi uji levene test sebesar 1,000>0,05 dengan demikian dapat diambil kesimpulan bahwa 3 kelompok sampel di atas bervarian sama atau homogen.

Karena data sampel penelitian ini terdistribusi normal dan bersifat homogen maka telah memenuhi syarat menggunakan Uji Statistik Parametrik yakni dalam hal ini uji Anova. Setelah dilakukan uji statistic ANOVA Berdasarkan tabel hasil analisis 4.6 digambarkan bahwa nilai signifikan $U j i$ Anova sebesar $1,000>0,05$ dengan demikian dapat diambil kesimpulan bahwa tidak ada perbedaan yang signifikan antara dahak yang diperiksa segera, tunda 3 jam, dan tunda 6 jam.

Dari hasil penelitian yang telah dilakukan di Balai Besar Kesehatan Paru Masyarakat Makassar (BBKPMM) didapatkan bahwa lama penyimpanan dahak pagipada suhu kamar tidak berpengaruh pada jumlah BTA $(\rho=1,000)$. Dengan demikian, hipotesis alternative pada penelitian ini ditolak dan hipotesis nol diterima.

Pada penelitian ini, peneliti membandingkan antara dahak pagi yang diperiksa segera, tunda 3 jam, dan tunda 6 jam untuk melihat adanya pengaruh lama penyimpanan dahak pagi pada jumlah bakteri tahan asam (BTA).

Penelitian ini ssesuai hasil penelitian Kalma dan Adrika (2018) mengemukakan bahwa jumlah BTA pada dua perlakuan spesimen dahak yaitu: spesimen dahak langsung diperiksa dan spesimen dahak ditunda pemeriksaannya. Berdasarkan hasil analisis data ternyata hasilnya tidak terdapat perbedaan yang bermakna, sehingga tidak ada pengaruh yang signifikan antara sampel dahak langsung dan sampel tunda 24 jam pada jumlah bakteri tahan asam (BTA). 


\section{KESIMPULAN}

Peneliti menyimpulkan bahwa perbedaan waktu lama penyimpanan dahak pagi pada suhu kamar tidak memberikan pengaruh selama 6 jam,

\section{SARAN}

Sebaiknya tetap menggunakan dahak pagi yang diperiksa segera. Namun dalam keadaan tertentu dahak pagi boleh dilakukan penundaan pemeriksaan hingga 6 jam.

\section{UCAPAN TERIMA KASIH}

Kami mengucapkan terima kasih kepada semua pihak yang telah membantu dalam penelitian ini, petugas laboratorium Balai Besar Kesehatan Paru Masyarakat Makassar, serta semua pihak yang tidak bisa disebutkan namanya satu persatu.

\section{DAFTAR PUSTAKA}

Aprianda Puji. 2018. Pusat Kesehatan Tuberculosis (TBC). Jakarta: Firdaus yusra

Budiharjo T. 2016. Pengaruh Penanganan Sputum Terhadap Kualitas Sputum Penderita TBC Secara Mikroskopik Bakteri Tahan Asam. Jakarta: Jurnal Riset Kesehatan..

Darmawati. 2013.Tuberculosis Menggunakan Dekontaminasi $\mathrm{NaOH}$, Jakarta:

Fujiki, A .2015. Mikroskopis Tuberculosis (TB) Untuk Program Tuberculosis Nasional. Jakarta:

Kalma Dan Adrika. 22018. Perbandingan Hasil Pemeriksaan Basil Tahan Asam Antara Spesimen Dahak Langsung Diperiksa Denga Ditunda 24 Jam. Jurnal Media Analis Poltekkes Kemenkes Makassar, Vol. 9. Http://Journal.Poltekkes-
Mks.Ac.Id/Ojs2/Index.Php/Me diaanalis/Article/View/682

Samiadi Aprilla Lika. 2017. Penyakit Tuberculosis (TBC). Jakarta: Tania Savitri. 
Tabel 01.

Distribusi Karakteristik Responden Berdasarkan Umur

\begin{tabular}{lll}
\hline $\begin{array}{c}\text { Umur } \\
(\text { Tahun })\end{array}$ & Frekuensi & Persentase \\
\hline $20-34$ & 5 & 55,6 \\
\hline $35-49$ & 3 & 33,3 \\
\hline $50-64$ & 1 & 11,1 \\
\hline TOTAL & $\mathbf{9}$ & $\mathbf{1 0 0}$ \\
\hline
\end{tabular}

Tabel 02.

Distribusi Karakteristik Responden Berdasarkan Jenis Kelamin

\begin{tabular}{ccc}
\hline Jenis Kelamin & Frekuensi & Persentase \\
\cline { 1 - 3 } Laki- Laki & 6 & 66,7 \\
\hline Perempuan & 3 & 33,3 \\
\hline TOTAL & $\mathbf{9}$ & $\mathbf{1 0 0}$ \\
\hline
\end{tabular}

Tabel 03.

Jumlah BTA berdasarkan lama penyimpanan Jumlah BTA

\begin{tabular}{cccc}
\hline No & Segera & Tunda 3 Jam & Tunda 6 Jam \\
\hline 1 & 2322 & 2315 & 2310 \\
\hline 2 & 1562 & 1560 & 1555 \\
\hline 3 & 410 & 405 & 400 \\
\hline 4 & 55 & 52 & 50 \\
\hline 5 & 750 & 747 & 745 \\
\hline 6 & 70 & 67 & 65 \\
\hline 7 & 556 & 553 & 550 \\
\hline 8 & 2153 & 2150 & 2147 \\
\hline 9 & 85 & 83 & 80 \\
\hline
\end{tabular}

Tabel 04. Hasil Uji Normalitas dengan Uji Shapiro-wilk

Shapiro-Wilk

\begin{tabular}{lcc}
\hline & Lama Penyimpanan & Sig. \\
Jumlah & BTA & \\
Bakteri & Segera & 0,061 \\
& Tunda 3 Jam & 0,060 \\
& Tunda 6 Jam & 0,060 \\
\hline
\end{tabular}


Tabel 05. Uji homogenitas Dat

Homogenity of Variances Test

\begin{tabular}{cc}
\hline Levene Statistic & Sig. \\
& 1,000 \\
\hline
\end{tabular}

Tabel 06. Uji Analysis Of Varians (ANOVA)

\begin{tabular}{|l|r|r|r|l|l|}
\hline & $\begin{array}{r}\text { Sum of } \\
\text { Squares }\end{array}$ & Df & $\begin{array}{r}\text { Mean } \\
\text { Square }\end{array}$ & F & Sig. \\
\hline Between & 206.741 & 2 & 103.37 & .000 & 1.000 \\
Groups & & & 0 & & \\
\hline Within Groups & 193992 & 24 & 808303 & & \\
& 79.560 & & .315 & & \\
\hline Total & 193994 & 26 & & & \\
& 86.300 & & & & \\
\hline
\end{tabular}

